перебували 198 хворих на ЦД 2 типу (ЦД2) з СДС. Вік пацієнтів становив від 39 до 76 років. Хворих розподілили на три групи: ті, які проживали 3 родиною; ті, які перебували частково під наглядом родичів; самотні. Протягом 12 місяців вивчали роль сім'ї в їх лікуванні. Проведено подвійний аналіз залежно від типу проживання та від того, з родичами або самостійно пацієнти відвідували лікаря.

Результати. Через 6 і 12 місяців у пацієнтів, які проживали 3 родиною, відзначено помітне зменшення кількості рецидивів СДС. У самотніх у ці терміни зафіксовано достовірне зростання кількості виразкових дефектів стоп. У групі «часткового нагляду» зменшення кількості рецидивів СДС набуло статистичної значущості лише через 1 рік. Також відзначено достовірне зменшення частоти розвитку гнійно-некротичних ускладнень серед пацієнтів, які відвідували лікаря в супроводі рідних.

Висновки. Наше дослідження довело, що недостатній контроль за дотриманням лікарських рекомендацій призводить до збільшення кількості рецидивів синдрому діабетичної стопи у пацієнтів 3 цукровим діабетом. Турбота родичів впливає

Дата надходження до редакції 23.10.2018 p. на позитивний результат лікування. Відмічено, що проживання в родині найбільшою мірою та достовірно покращує результати лікування. Зменшуються ризики виникнення рецидивів, тому що саме родичі контролюють прийом препаратів, проводять огляд нижніх кінцівок і за перших симптомів звертаються за допомогою.

Ключові слова: цукровий діабет, синдром діабетичної стопи, соціальний статус.

\section{ЛІТЕРАТУРА}

1. Yazdanpanah L, Nasiri $M$, Adarvishi S. Literature review on the management of diabetic foot ulcer. World Journal of Diabetes. 2015; 6(1):37-53.

2. Miller TA, Dimatteo MR. Importance of family/social support and impact on adherence to diabetic therapy. Diabetes Metab Syndr Obes Targets Ther. 2013; 6:421-426. doi:10.2147/ DMSO.S36368.

3. IDF Clinical Practice Recommendations on the Diabetic Foot - 2017. International Diabetes Federation. Clinical Practice Recommendation on the Diabetic Foot: A guide for health care professionals: International Diabetes Federation, 2017.

\title{
ФУНКЦІОНАЛЬНИЙ СТАН ТРОМБОЦИТІВ І ДІАБЕТИЧНА МАКУЛОПАТІЯ У ХВОРИХ НА ЦУКРОВИЙ ДІАБЕТ 2 ТИПУ
}

\author{
С.Ю. Могілевський, Ю.О. Панченко
}

Наџіональна медична академія післядипломної освіти імені П.Л. Шупика; м. Київ (Україна)

Діабетична ретинопатія (ДР) - одне 3 тяжких ускладнень цукрового діабету 2 типу (ЦД 2), що нерідко призводить до слабкозорості і сліпоти. Серед працездатного населення України в 2016 році іï поширеність становила 452,7 на 100000 населення, в 2017 році - 458,0 на 100000 [1]. Основною причиною зниження центрального зору у хворих ДР і ЦД $2 \epsilon$ діабетична макулопатія (ДМП) 3 розвитком діабетичного макулярного набряку (ДМН) [2, 3].

Мета - дослідити вплив системних (адреналін та ангіотензин-2 (Анг-2) та локальних (аденозиндифосфат (АДФ), фактор активації тромбоцитів (ФАТ) та колаген) чинників ЦД 2 типу на функціональний стан тромбоцитів (Тц) при
ДМП та ДМН при важкій непроліферативній та проліферативній стадіях діабетичної ретинопатії (НПДР, ПДР).

Матеріал та методи. В дослідження включено 42 пацієнта (42 ока) із цД 2 типу, у яких виявлена ДМП при ПДР (31 хворий, 31 око) і при важкій стадії НПДР (11 пацієнтів, 11 очей). Оцінку агрегації Тц in vitro у відповідь на АДФ, адреналін, Анг-2, ФАТ і колаген проводили турбидиметричним методом на аналізаторі ChronoLog (США).

Результати та їх обговорення. У всіх хворих виявлені загальні риси - гіперреактивність Тц на Анг-2 і адреналін, ФАТ і колаген, тобто активація ренін-ангіотензинової (РАС) і симпато-адреналової систем (САС), запалення і ремоделювання 
міжклітинного матриксу були неспецифічними механізмами патогенезу ДМП. Більша реактивність Тц до АДФ (p=0,008) при ПДР, ніж при важкій стадії НПДР, відображала особливості патогенезу ПДР. Причиною розвитку ДМН у хворих з ДМП може бути виразність дизрегуляції пуринергічної системи ока, активації РАС і запальної реакції, що проявлялося гіперреактивністю Тц до АДФ, Анг-2 і ФАТ, тоді як гіперреактивність Тц стосовно колагену була притаманною для відсутності ДМН.

Висновки. Аналіз Тц in vitro дозволив виявити механізми їх активації і з'ясувати провідні агоністи, які забезпечували участь Тц в прогресуванні ДМП та розвитку ДМН у хворих з важкою стадією НПДР і з ПДР при ЦД 2.

Дата надходження до редакиії 14.11.2018р.

\section{ЛITEPATУРА}

1. Офтальмологічна допомога в Україні за 20142017 роки / Аналітично-статистичний довідник. Кр-й «ПОЛІУМ», 2018. - 314 с. ISBN 978-966-855961-7.

2. Scholl S. General pathophysiology of macular edema / S. Scholl, A. Augustin, A. Loewenstein, S. Rizzo, B. Kupperman // Eur. J. Ophthalmol. - 2011. - Vol. 21, N. 6. - P. 10-19.

3. Диабетическая офтальмопатия / Под. ред. Л.И. Балашевича, А. С. Измайлова. - СПб.: Человек, 2012. - 396 c.

\title{
ВПРОВАДЖЕННЯ ОНОВЛЕНИХ КЕРІВНИХ НАСТАНОВ АМЕРИКАНСЬКОЇ ТИРЕОЇДНОЇ АСОЦІАЦЇ ПО ВЕДЕННЮ ХВОРИХ НА МЕДУЛЯРНИЙ РАК ЩИТОПОДІБНОЇ ЗАЛОЗИ
}

\author{
О.П. Нечай \\ Украйнський науково-практичний центр ендокринної хірургї, трансплантації ендокринних \\ органів і тканин МОЗ України
}

Вступ. Медулярний рак щитоподібної залози (МРЩ3) - це унікальний тип пухлини, що викликає зацікавленість дослідників в усьому світі. Постійний розвиток основних знань впливає на підходи клініцистів до діагностики та лікування. Регулярно публікуються та оновлюються рекомендації та консенсуси професійних товариств різних країн.

Мета: Вивчити ефективність генетичної діагностики МРЩЗ для оцінки його ризику серед родичів пацієнтів 3 попередньо встановленим діагнозом МРЩЗ - за використання оновлених керівних настанов Американської тиреоїдної асоціації (АТА, 2015 р.).

Матеріали і методи. Проаналізовано клінічні випадки генетичної діагностики МРЩЗ в пацієнтів із сімейним анамнезом патології, зокрема 3 використанням оновлених керівних настанов АТА щодо МРщЗ (2015 р.).

Результати та обговорення. 367 рекомендацій, наданих ATA, 25 стосуються генетичної діагностики МРЩ3. Запропоновано сучасні алгоритми ведення пацієнтів з МРЩ3. Оновлення переважно стосуються діагностики та спостереження за пацієнтами 3 цією нозологією, оскільки лікування МРЩЗ залишається універсально узгодженим - хірургічним, успіх його залежить від раннього встановлення діагнозу. Нині в Україні з'явилась можливість проведення генетичногодослідження,щодозволяєдіагностувати причинні мутації захворювання 3 подальшим відповідним веденням хворих та членів їх родин. Так, в нашій установі обстежено і проліковано трьох хворих з сімейним анамнезом МРЩз, яким було цілеспрямовано проведено генетичну діагностику і у яких було виявлено патогенні варіанти в гені RET (NM_020975.4). За результатами патогістологічного дослідження у двох хворих встановлена С-клітинна гіперплазія, у одного - пухлина розміром 4 мм категорії pT1aNOM0. Визначення генного дефекту вплинуло налікування, а саме-їхбулопрооперовано на ранній, доклінічній стадії хвороби, а також на визначення тактики подальшого спостереження за хворими та членами їх родин. Завдяки розширенню діагностичних можливостей, а також впровадженню керівних настанов АТА започатковано створення 